\title{
E depois da "Lei Eusébio"? Reprodução da escravidão e seus limites em um complexo de fazendas do vale do café (Rio de Janeiro, c. 1864-1888)
}

\author{
Thiago Campos Pessoa* \\ Universidade Federal Fluminense, Niterói, Rio de Janeiro, Brasil
}

\section{RESUMO}

Neste artigo discutiremos a reproduçâo do escravismo na área da grande lavoura fluminense após o fim do tráfico atlântico de africanos. Para tanto, tomaremos como objeto a demografia do complexo de fazendas do comendador Joaquim Breves, símbolo da expansão da escravidão no vale do café. Através de um dos livros de controle de suas fazendas, analisaremos o desenvolvimento demográfico do complexo. Demonstraremos que, de maneira ascendente, a partir do final da década de 1860 , se processou um amplo crescimento vegetativo naquela escravaria, movimento com apropriaçóes diferenciadas para o poder senhorial e a vida nas senzalas. Assim, analisaremos as dimensôes da reprodução da escravidão e seus limites nas duas décadas que precederam a ruína do escravismo na zona cafeeira fluminense.

Palavras-chaves: escravidão; demografia escrava; família escrava; Vale do Paraíba; cafeicultura escravista.

\section{RESUMEN}

En este artículo, discutiremos la reproducción del esclavismo en la grande área de agricultura fluminense después de la prohibición del tráfico atlántico de esclavos. En este sentido, tomaremos como objeto la demografía del complejo de las haciendas del Comendador Joaquim Breves, símbolo de la expansión de la esclavitud en el valle del café. A través de uno de los libros de control de sus haciendas, analizaremos el desarrollo demográfico del complejo. Demostraremos de forma ascendente que, a partir de finales de la década de 1860, ocurrió un amplio desarrollo vegetativo en aquella propiedad, situación que generó apropiaciones diferenciadas para el poder señorial y la vida en senzalas. De esta manera, examinaremos las dimensiones de la reproducción de la esclavitud y sus límites en las dos décadas que precedieron a su ruina en la zona cafetera fluminense.

DOI - http://dx.doi.org/10.1590/2237-101X01803602

Artigo recebido em 6 de junho de 2016 e aprovado para a publicação em 4 de maio de 2017.

* Pesquisador associado ao Laboratório de História Oral e Imagem (LABHOI) e ao Programa de Pós-Graduação em História da Universidade Federal Fluminense. Pesquisa financiada com bolsa de pós-doutoramento concedida pela FAPERJ. Email: tcpessoa@hotmail.com. 
E DEPOIS DA “LEI EUSÉBIO”? REPRODUÇÃO DA ESCRAVIDÃo E SEUS LIMITES EM UM COMPLEXO DE FAZENDAS DO VALE DO CAFÉ (RIO DE JANEIRO, C. I 864-I888)

Thiago Campos Pessoa

Palabras clave: esclavitud; demografía esclavista; familia esclava; Valle del Paraíba; caficultura esclavista.

\section{ABSTRACT}

In this paper, we will discuss the conditions for slavery reproduction in Rio de Janeiro's plantations after the end of the Atlantic slave trade. In order to do that, we studied the slavery demography of Commendator Joaquim Breves' plantations, which were a symbol of slavery expansion on the coffee valley. Through one of the plantations' registers, we analyze the demographical development in this complex of farms. We demonstrate that, after the 1860s, a broad vegetative growth in those plantations began to develop through a movement that had different meanings to slaves and their owners. Thus, we will analyze the dimensions of slavery reproduction, and its limits, in the two decades preceding the downfall of slavery in Rio de Janeiro's coffee plantations.

Keywords: slavery; slave demography; slave family; Paraíba Valley; coffee plantations.

Sem carregar nas tintas, muito provavelmente Joaquim José de Souza Breves era, individualmente, o maior proprietário de terras e almas no auge do Império do Brasil. Ao longo do século XX, muitas pesquisas esbarraram na figura emblemática de Breves. A partir de dados imprecisos, todas elas enfatizaram a vastidão do seu império. Não há consenso na discussão do quantitativo de escravos sob seu domínio. Nos trabalhos historiográficos os números giram entre 4 mil e 6 mil cativos. ${ }^{1}$ Relatos de época afirmam que Joaquim, sozinho, era senhor de 3 mil escravos. ${ }^{2}$ No ano da sua morte, era dono de 25 fazendas, sem contar sítios e terras, que escaparam aos avaliadores de seus bens, espalhados dos sertóes fluminenses até a fronteira com as Minas Gerais. ${ }^{3}$

Detentor de um perfil pouco comum ao universo escravista brasileiro, o "Rei do café" potencializou a reconfiguraçáo do escravismo em curso ao longo do oitocentos a partir do sul da antiga província do Rio de Janeiro, centralizando seu domínio no extinto município de São João do Príncipe, hoje Rio Claro. No âmbito demográfico, a trajetória de sua casa senhorial, ao mesmo tempo que se configura como exceção no universo da escravidão bra-

${ }^{1}$ Cf. LAMEGO, Alberto. O homem e a restinga. Rio de Janeiro: IBGE - Conselho Nacional de Geografia, 1946. CARVALHO, José Murilo de. Teatro das sombras. A política imperial. São Paulo: Vértice, 1988, p. 16. GRAHAM, Richard. Patronage and Politics in Nineteenth-century Brazil. Califórnia: Stanford University Press, 1989, p. 125-27.

${ }^{2}$ Arquivo Nacional (AN). Apelaçáo crime, 1874. Fundo: Tribunal da Relaçáo, no 3.368, maço 97, galeria A. ${ }^{3}$ Museu da Justiça do Estado do Rio de Janeiro (MJERJ). Autos de Avaliação. Inventário de Joaquim Breves (1890). V. 1, 2 e 3. 
E DEPOIS DA “LEI EUSÉBIO”? REPRODUÇÃO DA ESCRAVIDÃo E SEUS LIMITES EM UM COMPLEXO DE FAZENDAS DO VALE DO CAFÉ (RIO DE JANEIRO, C. I 864-I 888)

Thiago Campos Pessoa

sileira, reflete realidade tangível para outros senhores da área mais dinâmica do Império: o Vale do Paraíba. Lá, até os últimos anos do século XIX, a força da escravidão não estava em sua capilaridade; mas no reverso: na formação de unidades agrárias com centenas de indivíduos reduzidos ilegalmente à escravidão. Lá, senhores como Breves não eram tão incomuns assim. Por tudo isso, seu nome segue presente nas memórias produzidas desde o século XIX até os nossos dias. ${ }^{4}$

Não será nosso objetivo remontar com verossimilhança as antigas fazendas do comendador no período de grandeza da cafeicultura fluminense. A razão é simples: Joaquim Breves faleceu em setembro de 1889, um pouco mais de um ano após a abolição. Naquele momento suas propriedades já se encontravam em profunda decadência, destoando, assim, dos áureos anos de grandeza, evidente no médio Vale fluminense até a década de 1870. A utilização de seu inventário parece apropriada, especialmente, para a análise da crise que solapava as áreas pioneiras da economia do café na região fluminense. Assim, qualquer projeção retrospectiva sobre o auge do escravismo na região com base no seu espólio certamente produziria distorçóes e anacronismos. Dessa fase, restaram apenas fragmentos da documentação particular das fazendas, comum à administraçáo dos grandes complexos estruturados nas zonas de plantation.

A documentação produzida pela administração do conjunto das quase trinta fazendas do comendador conformava um grandioso acervo, possivelmente com todo o arrolamento da movimentação das fazendas nos circuitos locais e globais, esses últimos mediados pela praça do Rio de Janeiro. Nele também estariam evidentes os registros das transaçôes financeiras do fazendeiro-capitalista, fosse através das firmas constituídas no período ou mesmo nas transações financeiras em São João do Príncipe e Piraí. Uma pista importante da dimensão desse acervo aparece no momento em que Giovanni Streva, genro do finado Breves, assumiu como inventariante do espólio. Sua petição evidencia o que se perdeu:

Ao tomar conta do cargo de inventariante o suplicante requereu a intimaçáo de seu antecessor [Joaquim José de Souza Breves Filho] para lhe entregar todo o arquivo, do qual contava o registo das propriedades do espólio: o ex-inventariante não veio a juízo, e, pouco depois da intimação, faleceu. Sem conhecer todas as propriedades a inventariar, o suplicante tem lutado com sérios embaraços para descobrir-lhes o paradeiro; mas ultimamente veio a saber que $o$ arquivo está oculto em 10 grandes volumes, sendo 5 malas cobertas de couro; 3 grandes caixas com fechaduras; 2 grandes caixöes de pinho pregados, os quais foram removidos pelo ex-inventariante da fazenda Grama, onde residia e faleceu, para a casa de um lavrador vizinho de nome Joáo Cambraia, já falecido. (...). No interesse da conclusão do inventário quer o suplicante a V. Exa. mandado de apreensão dos referidos volumes em casa da viúva de João Cambraia, no sítio denominado "Manga Larga" a $3 \mathrm{~km}$ da freguesia do Arrozal do Piraí. (Grifo meu)

\footnotetext{
${ }^{4}$ Cf. Coletânea LABHOI-UFF. Passados Presentes, 2012. (4 DVDs)

${ }^{5}$ MJERJ. Inventário de Joaquim José de Souza Breves. V. 3, p. 651-51v.
} 
E DEPOIS DA “LEI EUSÉBIO”? REPRODUÇÃO DA ESCRAVIDÃo E SEUS LIMITES EM UM COMPLEXO DE FAZENDAS DO VALE DO CAFÉ (RIO DE JANEIRO, C. I 864-I 888)

Thiago Campos Pessoa

A petiçáo, protocolada em meados de 1916, se por um lado evidencia o volume de documentação produzida na gestáo do conjunto daquelas fazendas, por outro, curiosamente, indica que há quase um século o arquivo do comendador é objeto de disputas, permanecendo oculto. Muito provavelmente nessas malas, caixas e caixôes havia documentos de diversas naturezas, vinculados à estruturação do império dos Souza Breves, agigantado a partir do segundo quartel do século XIX. O valor do acervo perdido, obviamente, é incalculável. Para a posteridade restou apenas um livro de controle interno das fazendas do comendador, além de algumas outras folhas soltas, com registros da mesma natureza.

O livro ao qual nos referimos registrou os dados de nascimento, batismo, casamento e óbito de cativos das fazendas do complexo Breves entre 1864 e 1888. No entanto, não há proporcionalidade nem linearidade nessas informaçôes. Isso porque, enquanto o registro de nascimento seguiu até o ano da abolição, os arrolamentos de morte cessaram em 1876. Diferentemente dos assentos eclesiásticos, aqueles registros foram tabelados pelo guarda-livros do comendador, responsável pela escrituração e gerenciamento dos documentos produzidos na dinâmica de administração do complexo. Assim, trata-se de documentação privada, produzida na gestâo da casa, e que, por isso, além de ser bastante rara nos arquivos brasileiros, apresenta forma e, por vezes, conteúdo singular. ${ }^{6}$

$\mathrm{O}$ arrolamento dos nascimentos, por exemplo, não era prática comum, geralmente substituído pelo registro de batismo, nos termos do livro V das Ordenaçóes Filipinas, desde o início do período colonial. . $^{\mathrm{O}}$ controle senhorial contava com ambos, os nascimentos e os batismos sacramentados pelos párocos locais. Em relação aos casamentos, registraram-se apenas aquelas uniôes reconhecidas pela igreja. Não podemos dizer o mesmo sobre os óbitos, uma vez que não sabemos em que medida os registros do livro acompanharam os assentos eclesiásticos. Entretanto, a despeito do cruzamento da documentação particular aos assentos eclesiásticos, a escrituraçáo do nascimento à morte dos cativos de um dos maiores complexos de fazendas do Império ficaram registrados nesse livro, possivelmente um dos muitos existentes no escritório do comendador.

Assim, com os dados populacionais extraídos do livro de registros internos das fazendas de Joaquim, procuraremos analisar como, após o fim do tráfico atlântico, o antigo fazendeiro-traficante respondeu, nos limites das suas porteiras, a questão servil premente no Império na segunda metade da década de 1860. Para quem apostou no comércio negreiro com Áfri-

\footnotetext{
${ }^{6}$ Esse tipo de registro não configura exceção no universo senhorial oitocentista. Segundo o barão de Tinguá: "Entre os fazendeiros diligentes era uma prática catalogar (...) num livro de registros os nomes de escravos homens e mulheres, assim como seus filhos (...) e os nomes daqueles que morreram e daqueles (...) libertados quando batizados." Apud STEIN, Stanley. Vassouras: um município brasileiro do café (1850-1900). Rio de Janeiro: Nova Fronteira, 1990, p. 102, nota 56.

${ }_{7}$ Sobre o batismo de escravos, ver: Ordenaçóes Filipinas, Livro V, capítulo 99. LARA, Silvia (Org.). Ordenaçôes Filipinas. Livro V. São Paulo: Companhia das Letras, 1999, p. 308. Devemos enfatizar que no campo dos batismos, casamentos e óbitos, as Ordenaçôes seguiram regulando tais práticas até o processo de secularização realizado por lei em 1890.
} 
E DEPOIS DA “LEI EUSÉBIO”? REPRODUÇÃO DA ESCRAVIDÃo E SEUS LIMITES EM UM COMPLEXO DE FAZENDAS DO VALE DO CAFÉ (RIO DE JANEIRO, C. I 864-I 888)

Thiago Campos Pessoa

ca, para muito além dos seus limites institucionais, não era pequeno o problema posto com seu fim. No entanto, a estabilidade do escravismo angariada nos anos seguintes, garantida pelo inviolável direito à propriedade reafirmada pelo Estado, esvaneceu o sentimento de derrota para aqueles que se mantiveram tardiamente no ilícito trato. Nesse processo, proprietários de centenas, por vezes, milhares de africanos e seus descendentes rearticulariam suas estratégias a fim de projetar o funcionamento de suas unidades em um quadro em que a propriedade escrava, amealhada na ilegalidade, não era mais elemento instável, como pareceu nos primeiros anos da década de 1850 .

Duas décadas depois, a derrota foi ainda mais horizontal e contundente. A aprovação da Lei do Ventre Livre colocava de uma vez por todas o fim da escravidão no horizonte de todos os senhores do Império, e não por acaso foi por si só suficiente para rachar a coesão de classe estabelecida pelo Partido Conservador desde meados da década de $1830 .{ }^{8}$ A previsibilidade do fim da escravidão, por outro lado, exigiu dos grandes potentados, senhores de imensas escravarias na década de 1870, a reconfiguração do seu próprio domínio, que, apesar de não seguir mais assentado na propriedade jurídica sobre o trabalhador, tentaria manter as margens de domínio e controle social sobre a geração nascida após 28 de setembro de 1871. Através do retrato imperfeito das fazendas em destaque, ${ }^{9}$ procuraremos analisar as respostas encontradas por Joaquim Breves, na dialética relação entre senhor e comunidade, na perspectiva de sobrevida do seu complexo no avançar da década de 1870.

Nesse quadro se torna inevitável pensarmos na dimensão da família escrava no contexto da crise institucional da escravidão. Assim, em que medida a perspectiva do seu fim gradual, aberta pela Lei 2.040 de 28 de setembro de 1871, redimensionou a importância da família cativa no universo das grandes propriedades integradas a complexos de fazendas? Não nos referimos unicamente à dimensão da família como instrumento de controle senhorial, como delimitaram importantes pesquisas sobre o tema. ${ }^{10}$ Evidenciamos, especialmente, a apropriação dessa instituição como parte indispensável da estratégia de longevidade do domínio e submissão de matriz escravista, que não necessariamente estava vinculada ao estatuto da

${ }^{8}$ CARVALHO, José Murilo. A construção da ordem/Teatro de sobras. 3. ed. Rio de Janeiro: Civilização Brasileira, 2007, p. 291-328. PENA, Eduardo S. Pajens da casa imperial. Jurisconsulto, escravidão e a lei de 1871. Campinas: Ed. da Unicamp; CECULT, 2001. SALLES, Ricardo. E o vale era o escravo, Vassouras, século XIX. Senhores e escravos no coração do império. Rio de Janeiro: Civilização Brasileira, 2008, p. 41-134.

${ }^{9}$ Dissemos imperfeito porque as menores propriedades, provavelmente, ficaram fora do arrolamento realizado pelo guarda-livro. Assim, não foi registrado o desenvolvimento demográfico em Alto dos Negros; Cava Funda; José Elói; Jacuba; Mocumdu; Mendes e Sertão; Parado; Soledad; Santa Maria e Sipó. Outra hipótese é que os registros dessas unidades tenham ocorrido todos na fazenda-sede, sem referência aos locais de origem. Note-se que todas as unidades listadas foram descritas como fazendas do comendador no arrolamento dos seus bens. Auto de cálculo de partilha em 28 de maio de 1891. MJERJ. Inventário de Joaquim de Souza Breves. V. 2, p. 362-384

${ }^{10}$ Cf. MATTOS, Hebe. Das cores do silêncio: os significados da liberdade no sudeste escravista - Brasil, século XIX. Ed. rev. Campinas: Unicamp, 2013. FLORENTINO, Manolo; GOES, José Roberto. A paz nas senzalas: famílias escravas e tráfico atlântico, c.1790-c.1850. Rio de Janeiro: Civilização Brasileira, 1997. 
E DEPOIS DA “LEI EUSÉBIO”? REPRODUÇÃO DA ESCRAVIDÃo E SEUS LIMITES EM UM COMPLEXO DE FAZENDAS DO VALE DO CAFÉ (RIO DE JANEIRO, C. I 864-I888)

Thiago Campos Pessoa

propriedade escrava. Em outras palavras, buscaremos analisar como, diante do fim irreversível do processo de reiteraçáo da escravidão pelo mercado, alguns senhores, a exemplo de Breves, constituíram um quadro demográfico propício ao desenvolvimento vegetativo da população escrava e de seus descendentes livres nascidos após $1871 .^{11}$

A constituição de uma demografia favorável à ampliação dos vínculos familiares encontrava sua outra face na própria pressão imposta, naturalmente, por comunidades cativas formadas por centenas de indivíduos. Na delicada relaçáo entre agência escrava e limitaçôes estruturais, acreditamos que a ampliação dos vínculos nas comunidades de senzala, independentemente de ser encarada como conquista cativa ou concessão senhorial, parece ter sido estratégia compartilhada por cativos e senhores a partir de visóes diametralmente opostas. Para aqueles a família ampliada possibilitaria novas alianças, identidades e redes de proteção social; para os grandes fazendeiros a família, além de produzir a paz, e, consequentemente, a própria comunidade escrava, converter-se-ia em parte da estratégia de reestruturação da política de domínio e submissão diante da crise aberta naqueles anos.

Entre maio de 1864 e julho de 1888, mil trezentos e sessenta três (1.363) filhos de cativos nasceram em dezesseis fazendas do complexo Breves. Para termos uma dimensão da representatividade desses números no universo do Vale do Paraíba, vamos compará-los aos dados contidos no Recenseamento Geral do Império, referente ao ano de 1872, e ao Quadro demonstrativo do movimento da populaçáo escrava da Província do Rio de Janeiro, que abarca o período entre setembro de 1873 e agosto de $1882 .{ }^{12}$ Tomando por bases esses levantamentos, observamos que o quantitativo de rebentos das fazendas do comendador Breves representava cerca de quatro vezes e meia a populaçáo cativa, entre 1 e 15 anos, da Paróquia de N. S. da Conceição de Passa Três para o ano de 1872, sede de seu domínio. ${ }^{13}$ Uma década depois, em 31 de agosto de 1882, os nascidos no complexo eram equivalentes a nada menos que $60 \%$

\footnotetext{
${ }^{11}$ Como sabemos, o efetivo colapso do mercado de escravos só ocorreu nos primeiros anos da década de 1880, quando muitas províncias do Império elevaram substancialmente as taxas em torno das transaçóes envolvendo cativos, inviabilizando, assim, o comércio interno de escravos. Entretanto, a queda demográfica na população escravizada dos municípios de Piraí e São João do Príncipe, registrada desde o início da década de 1870, parece apontar que naqueles anos já havia um lento processo de esvaziamento das escravarias, paralelo ao crescimento do escravismo nas áreas mais dinâmicas do Vale oriental fluminense. Sobre o comércio interno para as zonas cafeeiras: Cf. SLENES, Robert. The demography and economics of brazilian slavery, 1850-1888. Tese (Doutorado em História) - Stanford University, Stanford, 1976. MOTTA, José Flávio. Escravos daqui, dali e de mais além: o tráfico interno de cativos na expansão cafeeira paulista. São Paulo: Alameda Editorial, 2012.

${ }^{12}$ IBGE. Diretoria Geral de Estatística. Recenseamento Geral do Império de 1872. Rio de Janeiro: Typ. Leuzinger/Tip. Commercial, 1876, 12 v. Província do Rio de Janeiro, p. 325. CRL. Brazilian Government Documents. Provincial Presidential Reports (1830-1930). Província do Rio de Janeiro. 1883.

${ }^{13} \mathrm{Na}$ referida paróquia foram listados 356 escravos entre 1 e 15 anos. Náo há registro de cativos nem de crianças livres, pretas ou pardas entre 0 e 12 meses.
} 
E DEPOIS DA “LEI EUSÉBIO”? REPRODUÇÃO DA ESCRAVIDÃo E SEUS LIMITES EM UM COMPLEXO DE FAZENDAS DO VALE DO CAFÉ (RIO DE JANEIRO, C. I 864-I888)

Thiago Campos Pessoa

de toda a população escrava, com menos de 21 anos de idade, atrelada ao universo rural no município de São João do Príncipe. ${ }^{14}$ A representatividade extraída dos cruzamentos dos dados desnuda a dimensão do desenvolvimento vegetativo no interior das comunidades de senzalas do comendador. Entretanto, esse perfil reprodutivo se distribuía irregularmente nas unidades do complexo. Ao todo, conseguimos associar $98,45 \%$ dos registros de nascimento (1.342 partos) às respectivas escravarias de origem, como vemos no gráfico a seguir.

\section{Gráfico 1: Quantitativo de nascimento de filhos de escravos nas fazendas do Complexo Joaquim Breves (1864-1888)}

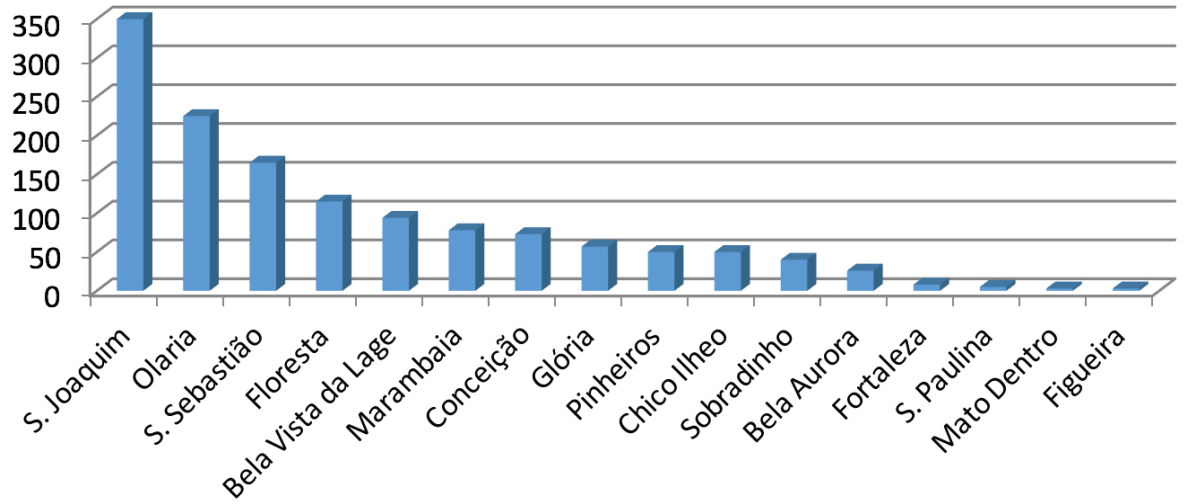

Fonte: Arquivo Municipal de Piraí (AMP). Livro de controle interno das fazendas do Comendador Joaquim Breves (1864-1888)

Obs.: $\mathrm{O}$ eixo vertical registra o número absoluto de nascimentos das fazendas em destaque. Foram excluídos do gráfico 21 registros para os quais náo localizamos as propriedades onde ocorreram os partos.

Como vemos, a distribuição dos nascimentos se estabeleceu de maneira desigual entre as fazendas em tela. Parece nítido sua predominância na sede do complexo. Em São Joaquim da Grama, entre 1868 e 1888, vieram ao mundo 350 crianças, quantitativo correspondente a $26,08 \%$ dos registros dessa natureza. Outras três propriedades tiveram mais de cem nascimentos no período: Olaria, São Sebastiáo e Floresta, com representatividade de 16,76\%; $12,29 \%$ e $8,56 \%$, respectivamente, em relação ao conjunto dos partos registrados. No outro extremo, encontramos poucos nascimentos nas escravarias da Fortaleza; Santa Paulina; Pinheiros e Mato Dentro. Ao todo, nessas unidades, nasceram 19 inocentes em quase vinte anos de arrolamento. ${ }^{15}$

\footnotetext{
${ }^{14}$ Em agosto de 1882, existiam 1.160 homens e 1.135 mulheres com menos de 21 anos dedicados aos serviços de campo no município de São João do Príncipe.

${ }^{15}$ Cabe uma observaçáo: a fazenda Mato Dentro aparece no livro até 1873 , após essa data não houve nenhum outro registro. Também não a encontramos nos autos de avaliação do espólio, o que pode indicar sua venda em algum momento a partir daquele ano.
} 
E DEPOIS DA “LEI EUSÉBIO”? REPRODUÇÃO DA ESCRAVIDÃo E SEUS LIMITES EM UM COMPLEXO DE FAZENDAS DO VALE DO CAFÉ (RIO DE JANEIRO, C. I 864-I 888)

Thiago Campos Pessoa

Muito embora a capacidade de reproduçáo interna se relacione, essencialmente, ao perfil demográfico de cada unidade, sua construçấo era, a priori, prerrogativa, e parte da estratégia da administração senhorial. Em que pese as determinaçôes estruturais, mediadas pelo caráter do mercado de escravos em sua conjuntura regional e local, ou ainda a margem de escolha dos próprios sujeitos escravizados; a dimensão do projeto de reestruturação da dominação passava, necessariamente, pelo estímulo à família escrava. Não por acaso seria nos limites da casa do comendador - a famosa fazenda de Sáo Joaquim da Grama - que se dera com maior intensidade o nascimento dos filhos dos últimos cativos do complexo. Era lá que a necessidade de estimular a consecuçáo de novos laços familiares, vinculada ao crescimento demográfico de sua população, se fazia premente. Não que a reprodução endógena também não se desse nas outras unidades. Somente na Olaria, em São Sebastião e na Floresta, quinhentos e cinco (505) indivíduos nasceram de mãe cativa no período destacado. Relembrando que essas três propriedades, assim como a Grama, também eram megafazendas, ou seja, unidades que muito provavelmente contavam com mais de cem cativos; e que para além do espaço da sede dispunham de alguns sítios que agigantavam sua dimensão. ${ }^{16}$ Somente elas quatro concentravam $63,71 \%$ dos nascimentos registrados.

Embora não haja dados que permitam traçarmos as taxas de fecundidade das fazendas, uma vez que não dispomos das listagens de suas escravarias, tudo indica que as megapropriedades apresentavam os maiores índices de nascimentos do complexo. Entretanto, pela experiência acumulada na análise minuciosa das fazendas do irmão do comendador, vimos que o tamanho da escravaria não parece indicador confiável sobre a frequência e ampliação dos vínculos familiares. Fatores relacionados com as características demográficas de cada unidade foram mais relevantes no processo de ampliação ou retração de tais vínculos. De fato, a eles se somavam também o projeto senhorial. Certamente a perspectiva de administração não excluía, necessariamente, opçôes individuais. Por isso, como no caso das propriedades de José Breves, irmão de Joaquim, encontramos unidades com até $100 \%$ dos cativos atrelados a laços de parentesco; enquanto em outras, menos da metade gozava de igual condição. A montagem dessa cartografia social certamente passava pelos interesses e perspectivas dos senhores em relação a cada unidade. Como escolhas quase sempre são condicionadas por diversos e diferentes contextos, identificar em que medida os senhores eram compelidos a estimular a formação desses vínculos, em determinadas unidades, parece tarefa de difícil solução. Entretanto, se guardamos relativa margem de autonomia, presente de maneira desigual em cada indivíduo, concluímos que a montagem dessas realidades demográficas era, a priori, escolha e prerrogativa senhorial. O desenvolvimento dessas realidades, no entanto,

\footnotetext{
${ }^{16}$ Utilizamos a proposta de Ricardo Salles, segundo a qual as unidades com mais de 100 cativos eram caracterizadas como megapropriedades. Cf. SALLES, Ricardo. E o vale era o escravo, Vassouras, século XIX. Senhores e escravos no coração do império, op. cit., p. 155.
} 
E DEPOIS DA “LEI EUSÉBIO”? REPRODUÇÃO DA ESCRAVIDÃo E SEUS LIMITES EM UM COMPLEXO DE FAZENDAS DO VALE DO CAFÉ (RIO DE JANEIRO, C. I864-I888)

possivelmente escapasse ao seu controle, mas seguia, em grande medida, condicionado às realidades constituídas vinte ou trinta anos antes.

Nessa perspectiva se assentava o estímulo ao crescimento demográfico de seus domínios. Esse processo, no entanto, só se torna perceptível se tomarmos como horizonte de análise a dimensão do complexo. Isso porque, se olharmos os nascimentos apenas na perspectiva de cada fazenda, tenderemos a diluir o seu impacto na dimensão do domínio senhorial. Por exemplo, em média, cerca de 24 indivíduos nasceram por ano na Grama, e em seus sítios anexos, entre 1868 e $1888 .{ }^{17}$ Visto dessa forma, até mesmo onde a reprodução era mais frequente, os números podem não aquilatar, por si só, a dimensão do crescimento daquelas comunidades. Entretanto, se deixarmos de olhar realidades individuais e tomarmos por objeto os nascimentos no complexo em escala longitudinal, encontraremos uma nova dimensão.

\section{Gráfico 2: Nascimentos no Complexo Joaquim Breves (1864-1888)}

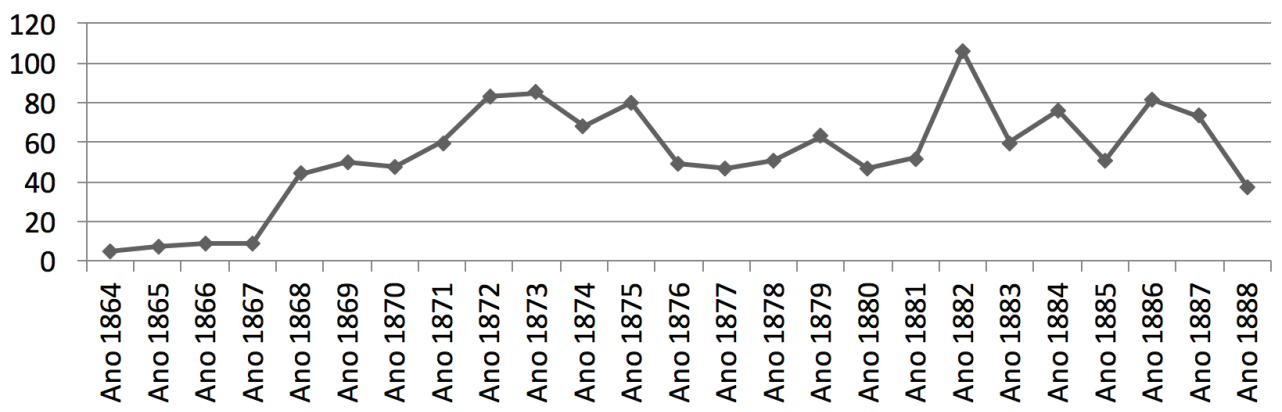

Fonte: AMP. Livro de controle interno das fazendas do Comendador Joaquim Breves (1864-1888).

Obs.: $\mathrm{O}$ eixo vertical registra o número absoluto de nascimentos. Vinte e um registros não foram incluídos no gráfico porque não foi possível saber em quais anos ocorreram.

Embora tenhamos construído o gráfico levando em conta todos os registros, devemos destacar que entre 1864 e 1867 apenas os nascimentos em São Sebastiáo foram catalogados. Só a partir de 1868 outras fazendas começaram a compor as anotaçóes do guarda-livro. Naquela ocasiấo foram incluídos os nascimentos na Olaria, na Conceição e em São Joaquim da Grama. Paulatinamente outras realidades iam surgindo. Em 1875, já havia quinze comunidades registradas. Portanto, é evidente que os primeiros anos não incorporaram todos os partos realizados na dimensão do complexo, gerando, com isso, subnotaçáo. Da mesma forma, a linha ascendente a partir de 1867 parece consequência direta da incorporaçáo das demais unidades.

Apesar disso, a crítica à fonte parece reveladora. Ainda que interpretemos o crescimento estampado até 1872 apenas como o movimento gradual de incorporação de novos

\footnotetext{
${ }^{17}$ Excluímos desse percentual os anos de 1876-1877; 1883-1884, quando nenhum registro de nascimento apareceu associado ao universo de São Joaquim da Grama.
} 
E DEPOIS DA “LEI EUSÉBIO”? REPRODUÇÃO DA ESCRAVIDÃo E SEUS LIMITES EM UM COMPLEXO DE FAZENDAS DO VALE DO CAFÉ (RIO DE JANEIRO, C. I 864-I 888)

Thiago Campos Pessoa

registros de fazendas antes não catalogadas, e não necessariamente como crescimento vegetativo, fica uma pergunta: por que, a partir de meados dos anos de 1860, passou-se a contabilizar os nascimentos dos filhos dos cativos do complexo? Mesmo diante da efetivação da lei de 1871, ou seja, com o efetivo fim da reprodução endógena da escravaria, quais fatores motivavam o registro crescente dos filhos dos cativos, ainda que ingênuos fossem, até dois meses após a abolição?

A fim de respondermos, ainda que parcialmente, as questôes anteriormente formuladas, vale adensarmos a análise do gráfico. Já fizemos referência ao crescimento dos registros até o início de 1870, entretanto, devemos destacar que a retração anunciada na segunda metade daquela década, possivelmente, estava relacionada com o encolhimento do universo em análise. Isso porque das quinze fazendas catalogadas em 1875, apenas nove apareceram entre 1876-77, ficando de fora grandes comunidades como aquelas situadas na Grama e na Floresta. Pelo volume de nascimentos registrados nas unidades nos anos anteriores, achamos improvável que não tivesse ocorrido sequer um parto naquele biênio. Talvez fosse mais acertado dizer que os dados daquelas realidades, por motivo que desconhecemos, náo foram incluídos para os referidos anos. Em certa medida, o mesmo ocorreu em 1883, quando os números da Grama também ficaram de fora dos registros. Entretanto, entre 1881 e 1882, os nascimentos se ampliaram em mais de $100 \%$, elevando a queda no período seguinte. No ano da abolição, os dados seguiram dois meses após o 13 de Maio. Registraram-se trinta e sete (37) nascimentos em apenas quatro fazendas.

Pensando na realidade aberta pela Lei do Ventre-Livre, os partos realizados, após 1871, nas fazendas do comendador se tornam ainda mais significativos, sobretudo se cruzados aos números de ingênuos registrados na mesma época no município de São João do Príncipe, sede de boa parte daquelas comunidades. Vejamos melhor o que dizemos.

Tabela 1: Relação entre ingênuos matriculados no município de São João do Príncipe e aqueles nascidos no complexo Breves (1872-1875)

\begin{tabular}{|c|c|c|}
\hline Ano referência & Matriculados por ano & \% em relação ao complexo Breves \\
\hline Ano 1872 & 308 & $26,94 \%$ \\
\hline Ano 1873 & 378 & $22,48 \%$ \\
\hline Ano 1874 & 178 & $38,20 \%$ \\
\hline Ano 1875 & 248 & $28,16 \%$ \\
\hline Total/média & 1112 & $28,95 \%$ \\
\hline
\end{tabular}

Fonte: Mapa especial do movimento da população ingênua até 31 de dezembro de 1877 nos diversos municípios da Província do Rio de Janeiro. Center Research Libraries (CRL). Brazilian Government Document Digitalization Project. Provincial Presidential Reports (1830-1930): Rio de Janeiro, 1878. 
A Tabela 1 redimensiona a importância dos nascimentos de ingênuos no complexo. Entre 1872 e 1875, em média, 28,95\% dos indivíduos nascidos de mãe escrava no município de São João do Príncipe estavam vinculados às fazendas de Breves. Em alguns momentos, como se observa no ano de 1874, esse índice subia para mais de 38\%. A dimensão do seu conjunto de propriedades ajuda a explicar a alta representatividade do índice, que parece revelar a ampliação dos laços familiares e o crescimento da fecundidade naquelas comunidades. Assim, desconsiderando, a princípio, a elevada taxa de mortalidade infantil, temos que cerca de três em cada dez crianças nascidas de mãe cativa em São João do Príncipe se tornariam potenciais trabalhadores das fazendas do comendador. Isso porque, até o dia 31 de dezembro de 1878, das 1.373 crianças nascidas no município, apenas quinze haviam deixado São João do Príncipe com seus pais, e outras treze foram entregues ao Estado "pela renúncia dos serviços por parte dos senhores das suas mäes". ${ }^{18}$

Feitas as devidas ressalvas, caminhemos para o que de fato interessa como hipótese central deste artigo. O nascimento de cerca de 1.360 indivíduos, cativos e ingênuos, nos últimos 25 anos de escravidão no Império, indica que, para além da ampliação dos vínculos familiares, o desenvolvimento demográfico promovido pelo ventre das cativas tinha um impacto direto na possibilidade de sobrevida do complexo de fazendas do comendador. Isso porque os ganhos contidos nos nascimentos dos novos sujeitos seriam significativos. Muitos deles, ainda que nascidos livres, continuavam vistos como "crias" das fazendas, e nelas permaneceriam compelidos à prestação de serviços até completarem 21 anos. ${ }^{19}$ Do ponto de vista do governo dos escravos e seus dependentes, os simples registros dos ingênuos são elucidativos, uma vez que trazem à tona a perspectiva senhorial de contabilizar e amealhar a renda política e econômica advinda da consecução dos vínculos familiares, e, especialmente, o resultado mais efetivo desses laços.

Antes de avançarmos, devemos esclarecer melhor onde queremos chegar com o acompanhamento de parte da populaçáo do complexo. Para tanto, optamos por cruzar o quantitativo do nascimento aos óbitos registrados no conjunto daquelas fazendas entre os anos de 1865 e 1875. Vejamos o resultado a partir do gráfico a seguir.

${ }^{18}$ CRL. Brazilian Government Document Digitalization Project. Provincial Presidential Reports (18301930). Quadro estatístico dos filhos livres de mulher escrava, matriculados até 31 de dezembro de 1878 com as alteraçóes ocorridas até aquela data. Rio de Janeiro, 1879.

${ }^{19}$ Nunca é demais lembrar que a Lei Áurea, em dois artigos, aboliu irrestritamente a escravidão e todas as disposiçóes em contrário; livrando, inclusive, aqueles ingênuos da prestação de serviços que estavam submetidos, segundo a Lei 2.040 de 28 de setembro de 1871 . 
E DEPOIS DA “LeI EUSÉBIO”? REPRODUÇÃO DA ESCRAVIDÃo E SEUS LIMITES EM UM COMPLEXO DE FAZENDAS DO VALE DO CAFÉ (RIO DE JANEIRO, C. I 864-I 888)

Thiago Campos Pessoa

\section{Gráfico 3: Relação entre o quantitativo de nascimentos e óbitos nas fazendas do comendador (1865-1875)}

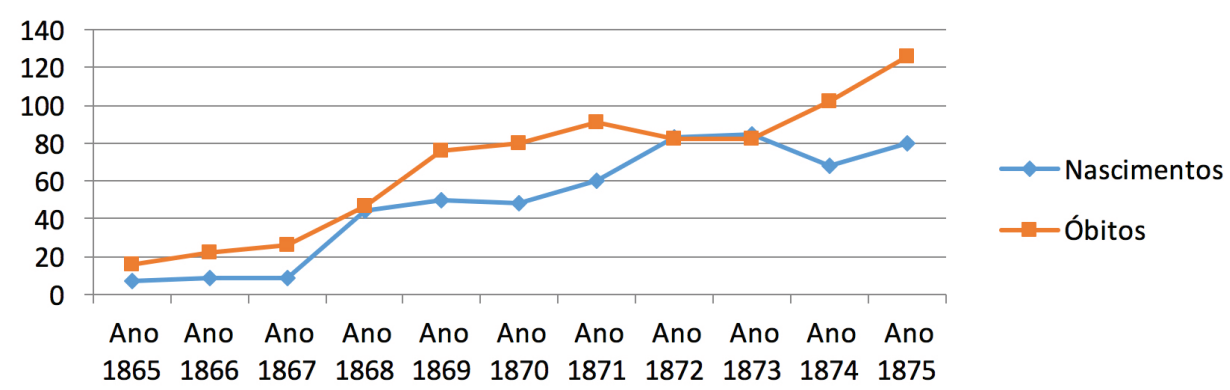

Fonte: AMP. Livro de controle interno das fazendas do Comendador Joaquim Breves (1864-1888).

Obs.: $\mathrm{O}$ eixo vertical registra o número absoluto de nascimentos e óbitos. As fazendas registradas nos nascimentos se repetiram nos óbitos, com exceção de Santa Paulina, que não aparece no segundo registro.

A princípio, comparando a linha de evolução entre nascimentos e óbitos, não poderíamos afirmar que houvesse um processo de crescimento vegetativo naquelas comunidades entre meados da década de 1860 e os dez anos seguintes. Como vemos, ao longo dos anos, aumentou a distância entre o quantitativo dos que morriam em relaçáo à natalidade. Se havia uma tendência ao equilíbrio no final daquela década, ela parece ter sido revertida pelo crescente envelhecimento da escravaria, e, consequentemente, pelo aumento dos índices de mortalidade. Então, poderíamos concluir que a perspectiva de ampliação demográfica daquelas comunidades, através da reprodução endógena de sua população, tenderia naturalmente ao fracasso? Não exatamente. Observemos melhor o perfil de mortalidade na realidade do complexo.

Tabela 2: Representatividade dos óbitos por faixa etária

\begin{tabular}{|c|c|}
\hline Faixas etárias & \% de óbitos \\
\hline 0 a 14 & $33,64 \%$ \\
\hline 15 a 29 & $5,89 \%$ \\
\hline 30 a 44 & $16,38 \%$ \\
\hline 45 a 59 & $23,27 \%$ \\
\hline 60 ou mais & $20,82 \%$ \\
\hline
\end{tabular}

Fonte: AMP. Livro de controle interno das fazendas do Comendador Joaquim Breves (1864-1888).

Através dos dados da Tabela 2, vemos que um pouco mais de um terço dos óbitos relacionava-se a sujeitos entre 0 e 14 anos; sendo que, na composição desse percentual, 28,60\% morriam entre 0 e 4 anos; 3,6\% entre 5 e 9 anos, e 1,44\% dos 10 aos 14 anos. Sendo assim, durante a infância, a probabilidade de morte era imensamente superior nos quatro primeiros anos de vida. A redução da mortalidade nas faixas seguintes assegurava que muitos dos 
E DEPOIS DA “LeI EUSÉBIO”? REPRODUÇÃO DA ESCRAVIDÃo E SEUS LIMITES EM UM COMPLEXO DE FAZENDAS DO VALE DO CAFÉ (RIO DE JANEIRO, C. I 864-I 888)

inocentes que sobrevivessem aos primeiros 48 meses em aproximadamente dez anos se converteriam em potenciais trabalhadores das fazendas do comendador. Soma-se a isso a baixa representatividade dos óbitos dos indivíduos em sua fase mais produtiva: apenas 12,06\% desses registros envolviam sujeitos de 15 a 40 anos; enquanto mais da metade das mortes $54,30 \%$ - abarcava cativos com mais de 40 anos, a grande maioria homens africanos. Entre os adultos, em cada dez óbitos, sete arrolavam a morte de africanos.

Apesar disso, inegavelmente as altas taxas de mortalidade nos primeiros anos de vida e o processo de envelhecimento da escravaria implicavam retraçáo no desenvolvimento da demografia do complexo. O que não significa, por outro lado, que não fosse interessante, do ponto de vista senhorial, a ampliação das famílias cativas, especialmente porque o número de crianças que sucumbiam diante das enfermidades que atingiam as senzalas era muito menor do que aquelas que chegariam e, não raramente, ultrapassariam a fase adulta nas fazendas. Vejamos o gráfico a seguir.

\section{Gráfico 4: Cruzamento entre nascimentos e óbitos de indivíduos de 0 a 14 anos}

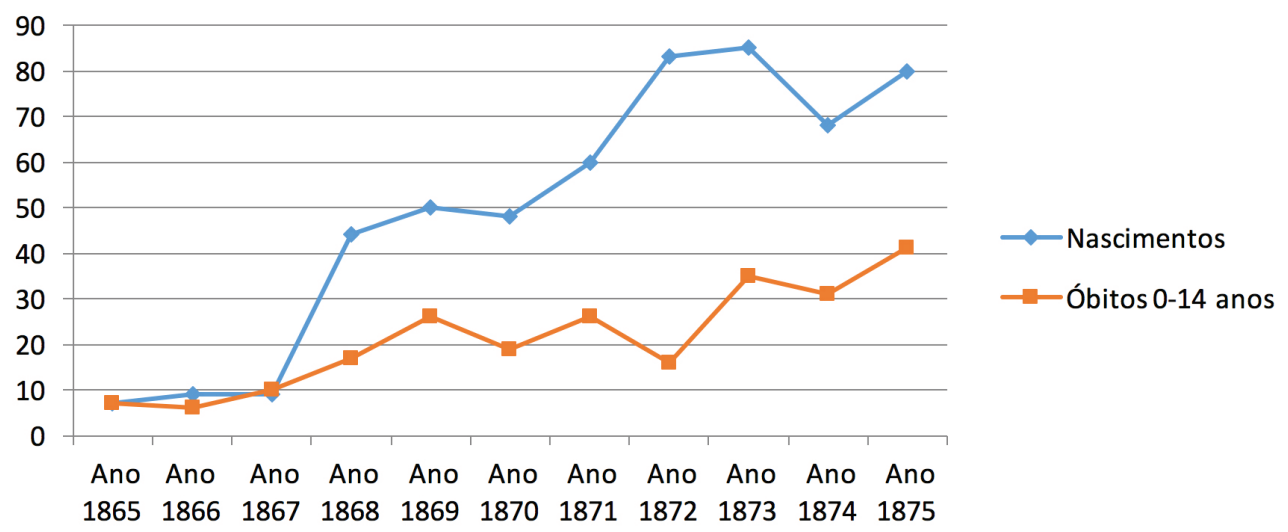

Fonte: AMP. Livro de controle interno das fazendas do Comendador Joaquim Breves (1864-1888) Obs.: $\mathrm{O}$ eixo vertical registra o número absoluto de nascimentos e óbitos.

Como vemos, comparando apenas aqueles indivíduos falecidos entre 0 e 14 anos, que juntos totalizavam 33,64\% dos óbitos, aos filhos de cativos nascidos no mesmo período, vemos que, a partir do final da década de 1860, o incremento no número de nascimentos significava também uma projeção positiva em relação ao desenvolvimento vegetativo do complexo. Se até 1867 havia uma paridade entre nascimentos e óbitos, nos oito anos seguintes a elevação da natalidade, ainda que provocasse um crescimento no número de óbitos, garantia que a maior parte daqueles que nascessem chegaria à vida adulta, e, consequentemente, se converteria em trabalhadores vinculados àquelas comunidades. Descontado os óbitos vinculados aos indivíduos menores de 14 anos, podemos afirmar que, emblematicamente, na iminência da aprovação da lei que libertava o ventre escravo, a reprodução endógena da de- 
E DEPOIS DA “LeI EUSÉBIO”? REPRODUÇÃO DA ESCRAVIDÃo E SEUS LIMITES EM UM COMPLEXO DE FAZENDAS DO VALE DO CAFÉ (RIO DE JANEIRO, C. I 864-I888)

mografia daquelas comunidades começava a funcionar. A partir de então, o quantitativo de nascimentos superaria o número de crianças falecidas nos mesmos anos.

\section{Gráfico 5: Diferença entre nascimentos e óbitos de indivíduos de 0 a 14 anos}

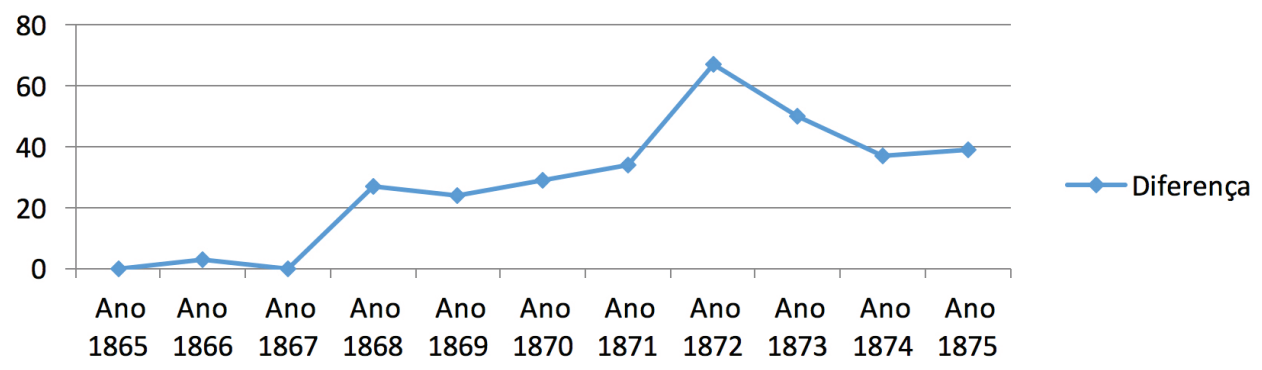

Fonte: AMP. Livro de controle interno das fazendas do Comendador Joaquim Breves (1864-1888).

Obs.: $\mathrm{O}$ eixo vertical registra em números absolutos a diferença entre nascimentos e óbitos de crianças entre 0 e 14 anos.

Se a princípio não podemos afirmar que havia um crescimento vegetativo ampliado naquela realidade; de igual modo o elevado número de nascimentos encontrados não era sem razão, e tampouco estava simplesmente relacionado com o desenvolvimento demográfico daquelas fazendas. Sabendo que grande parte das crianças alcançaria a fase adulta, parecia se concretizar um projeto comum, com duas partes interessadas, muito embora com expectativas antagônicas. De um lado a família escrava, que projetava sua ampliação na tessitura de novos vínculos assentados em experiências e heranças compartilhadas, como sinônimo de autonomia, e, sobretudo, perspectiva de ampliação da liberdade. ${ }^{20}$ De outro, os senhores da grande lavoura, que possivelmente viam na ampliação dos lares escravos não só a renda política advinda da promoção da paz e da própria construção da comunidade escrava, ${ }^{21}$ mas, sobretudo, caminho possível para a sobrevida de suas fazendas, através da reprodução interna de sua demografia.

A perspectiva de que essas crianças chegariam à vida adulta acalentava escravos e senhores, não sem razão. Ainda que os percentuais de mortalidade fossem muito elevados nas idades de 0 a 4 anos, eles tendiam a diminuir nas duas faixas seguintes -5 a 8 anos; 9 a 15 anos — , garantindo, assim, a sobrevivência de maior parte dos nascedouros, quase sempre em escala superior ao quantitativo das crianças que faleciam na mesma época. Em outras palavras, havia boas razóes para se acreditar que os filhos dos cativos nascidos naquelas propriedades de fato chegariam à vida adulta, convertendo-se em trabalhadores: cativos

\footnotetext{
${ }^{20}$ SLENES, Robert. Na senzala uma flor: esperanças e recordaçóes da família escrava — Brasil, Sudeste século XIX. Rio de Janeiro: Nova Fronteira, 1999.

${ }^{21}$ FLORENTINO, Manolo; GÓES, José Roberto. A paz das senzalas: famílias escravas e tráfico atlântico, c.1790-c.1850, op. cit.
} 
E DEPOIS DA “LEI EUSÉBIO”? REPRODUÇÃO DA ESCRAVIDÃo E SEUS LIMITES EM UM COMPLEXO DE FAZENDAS DO VALE DO CAFÉ (RIO DE JANEIRO, C. I 864-I 888)

Thiago Campos Pessoa

no caso dos 203 indivíduos nascidos antes da Lei do Ventre Live; e agregados, em relação aos demais, presos aos laços familiares e à obrigaçáo de prestarem os devidos serviços até completarem 21 anos.

Muito por conta disso, a redução da mortalidade era uma preocupação comum aos manuais agrícolas de época. No momento de expansão da escravidão, e, consequentemente, a partir da montagem das grandes escravarias do complexo cafeeiro, a questão do tratamento dispensado aos escravos aparece como ponto de convergência naquelas obras. Nos textos analisados por Rafael Marquese, produzidos entre 1834 e 1866, a saúde dos cativos e o estímulo à família escrava, vista como elemento estabilizador e disciplinador da gestão da escravaria, emergem como pautas compartilhadas por todos os senhores que buscaram refletir sobre a administração de grandes fazendas ao longo do oitocentos, antes e após o fim do tráfico. ${ }^{22}$

Os textos analisados por Marquese demonstram claramente quais eram os pontos a serem considerados na gestáo da escravaria entre os anos de 1830 e a década de 1860 . Nessa perspectiva questôes como moradia, alimentação, saúde, instrução religiosa, acesso à roça própria e à família escrava apareciam como pontos comuns em todos aqueles manuais. No entanto, entre as várias preocupaçóes uma parecia cada vez mais premente: a reprodução endógena da escravidão. ${ }^{23}$ Certamente o contexto da primeira metade dos anos de 1830 , aberto com a ilegalidade do tráfico em 7 de novembro de 1831, era bastante propício a projeção da continuidade da escravidão no Império via a reprodução interna de seus cativos, como previa Carlos Augusto Taunay em 1836:

A escravidão dos crioulos é a mais difícil de justificar do que a dos pais comprados na Costa. O filho segue a mãe, filius ventris sequitur; esta máxima do direito baseia-se na precisão que o parto tem para viver do leite da mãe, e do pão do senhor desta. A lei considera que o senhor trataria da cria e não faria desembolsos durante a longa duração da infância, se não tivesse em perspectiva o trabalho do resto da vida $\mathrm{O}$ voto da lei legitima a este respeito o jus do senhorio. Aqui se levanta outra questão. Terá o senhor o direito de obrigar os seus escravos a produzirem filhos? Responderemos que nem tem direito, nem precisão disso e que para o conseguir bastará

\footnotetext{
${ }^{22}$ Para o caso brasileiro, os autores e as obras analisadas por Marquese foram os seguintes: Miguel Calmon du Pin de Almeida, Ensaio sobre o fabrico de açúcar, 1834; Carlos Augusto Taunay, O manual do agricultor brasileiro, 1839; Francisco Peixoto de Lacerda Werneck, Memória sobre a fundação de uma fazenda na Província do Rio de Janeiro, 1847; Luís Peixoto de Lacerda Werneck, Ideias sobre colonização, precedidas de uma sucinta exposição dos princípios gerais que regem a população, 1855, e Antônio Caetano da Fonseca, Manual do agricultor dos gêneros alimentícios, 1863. MARQUESE, Rafael. Feitores do corpo, missionários da mente: senhores, letrados e o controle dos escravos nas Américas, 1660-1860. São Paulo: Companhia das Letras, 2004, p. 259-298.

${ }^{23}$ Ricardo Salles enfatizou a questão da reprodução endógena vista através dos manuais analisados por Marquese, cf. SALLES, Ricardo. E o vale era o escravo, Vassouras, século XIX. Senhores e escravos no coração do império, op. cit., p. 237-271.
} 
E DEPOIS DA “LEI EUSÉBIO”? REPRODUÇÃO DA ESCRAVIDÃo E SEUS LIMITES EM UM COMPLEXO DE FAZENDAS DO VALE DO CAFÉ (RIO DE JANEIRO, C. I 864-I 888)

Thiago Campos Pessoa

não contrariar a natureza que convida os sexos a se reunirem (...) Casadas ou solteiras, as pretas prenhes devem ser tratadas com mimo e aplicadas a um trabalho moderado. O parto e a amamentação merecem as competentes atençóes. Os filhos, depois de desmamados, deverão ser criados em comum em classes conforma a idade (...) e a proporçấo que se criando, se lhes ensinará trabalhar, a rezar, a amar seus senhores, suportar o frio, o calor, a fadiga e a seguir à risca a disciplina da casa. $\mathrm{O}$ mesmo se observará com as crioulas, que serão criadas à parte. Dessa forma uma nova geração, mais instruída, jeitosa, disciplinada e virtuosa do que a que veio da Costa, suprirá as faltas desta, e pouco a pouco substituirá inteiramente. ${ }^{24}$

O texto de Taunay, contemporâneo à expansão da escravidão no Vale cafeeiro, certamente dialogava com a perspectiva sobre o fim da reiteração da escravidão via mercado atlântico, e, nesse sentido, a atenção à família, e aos cuidados à saúde cativa, seguia colada à perspectiva de reprodução endógena da escravaria. Naquele momento, por mais que pesassem concepçóes ilustradas nas suas recomendaçóes, parecia evidente que a reiteração da escravidão no marco das grandes fazendas era objeto de crescentes interesses, não só de Taunay, mas de outros senhores que refletiam sobre a gestão dos grandes complexos escravistas.

Essa era a perspectiva do filho do barão de Paty do Alferes — Luís Peixoto de Lacerda Werneck - herdeiro de um complexo de fazendas semelhante ao que analisamos. Influenciado pela posição de um viajante que conhecera a escravidão na Virgínia no final dos anos de 1830, afirmava enfaticamente que "os lavradores deviam promover por todos os meios a propagação dos escravos, uma vez que esses meios sejam de acordo com a moral e a religião. Nessa obra meritória conciliam-se os interesses do futuro da agricultura, e no mesmo tempo, a caridade cristã". ${ }^{25}$

Para Lacerda Werneck os meios para se alcançar a dita "propagação dos escravos" continuavam sendo o cuidado com as mulheres grávidas, com os recém-nascidos e com as crianças; além do zelo à saúde em seu sentido mais amplo, abarcando atenção à moradia, alimentação e possíveis enfermidades contraídas ao longo da vida em cativeiro. Caetano Fonseca, contemporâneo de Werneck, ratificava os cuidados às escravarias, especialmente às grávidas, que durante a gestação deveriam ser poupadas, evitando assim "serem tratadas com rigor; porque isto muitas vezes é causa de abortos; supressão das regras, e de muitos outros inconvenientes". A mesma atenção era dedicada à criança, especialmente no "tempo de dentição", momento em que as taxas de mortalidade eram mais elevadas, como vimos. ${ }^{26}$

${ }^{4}$ TAUNAY, Carlos Augusto. Manual do agricultor brasileiro. Organização Rafael Marquese. São Paulo: Companhia das Letras, 2001, p. 78-81.

${ }^{25}$ WERNECK, Luís Peixoto de Lacerda. Ideias sobre a colonização precedidas de uma sucinta exposição dos princípios gerais que regem a população. Rio de Janeiro: E \& H. Laemmert, 1855, p. 23-24, apud SILVA, Eduardo. Baróes e escravidão - três geraçóes de fazendeiros e a crise da estrutura escravista. Rio de Janeiro: Nova Fronteira, 1984, p. 202.

${ }^{26}$ Apud MARQUESE, Rafael. Feitores do corpo, missionais da mente: senhores, letrados e o controle dos escravos nas Américas, 1660-1860, op. cit., p. 288 e 290-291. Sobre a questão da saúde escrava no século XIX, 
E DEPOIS DA “LEI EUSÉBIO”? REPRODUÇÃO DA ESCRAVIDÃo E SEUS LIMITES EM UM COMPLEXO DE FAZENDAS DO VALE DO CAFÉ (RIO DE JANEIRO, C. I 864-I 888)

Thiago Campos Pessoa

As recomendaçóes de Fonseca, escritas no início da década de 1860, indicam quais eram as perspectivas dos senhores em relaçáo ao futuro das proles de suas cativas:

Quando os meninos passarem de cinco anos devem ir aprendendo alguma doutrina cristã, e principiar a trabalhar em serviços que forem compatíveis com suas forças, porém por pouco tempo; pois é isso tăo somente para moralizá-los, e para desenvolver e fortificar os seus músculos, e não para tirar fruto do seu trabalho; pois só de dez anos por diante pode dar algum serviço aos seus senhores. ${ }^{27}$

A reprodução da escravidáo nos marcos do Império não era necessariamente uma novidade naquele momento, uma vez que perspectivas semelhantes apareceram no contexto de ilegalização do tráfico de africano na segunda metade dos anos de $1820 .{ }^{28}$ Entretanto, somente com o fim efetivo do comércio negreiro em escala atlântica a perspectiva de reprodução endógena parece ganhar força.

Tomando a realidade de Vassouras como exemplo, Ricardo Salles analisa que desde os anos 1820 havia uma tendência ao crescimento do número de filhos de cativos naquelas escravarias. Comparando os nascimentos do período marcado entre 1820 e 1850 com aqueles ocorridos de 1861 a 1870, infere que o quantitativo da década de 1860 foi quase quatro vezes maior que o registrado no segundo quartel do século. Esse padrão, aliás, continuava em ascensão na década da Lei do Ventre Livre. A reprodução natural parece límpida em Vassouras após o fim do tráfico. Segundo Salles, o quantitativo de batismos de escravos era superior aos falecimentos em média 0,85\% entre 1853 e 1855, "implicando em taxas presumiveis de crescimento natural para essa parcela da população". De 1873 até 1884, o número de nascimentos (5.182) continuava superando os óbitos (4.052), e o crescimento daquela populaçáo atingiu a média de $0,78 \%$ ao ano. Dito de outra forma, havia, naqueles anos, uma conjuntura propícia à reprodução da demografia das fazendas de Vassouras. Nesse quadro, corroboramos a defesa de uma sociedade escravista madura, caracterizada por uma comunidade escrava estável,

Cf. PORTO, Ângela. O sistema de saúde do escravo no Brasil do século XIX: doenças, instituiçóes e práticas terapêuticas. História, Ciências, Saúde - Manguinhos, Rio de Janeiro, v. 13, n. 4, p. 119-127, out./dez. 2006. EUGÊNIO, Alisson. Reflexôes médicas sobre as condições de saúde da populaçáo escrava no Brasil do século XIX. Afro-Ásia, n. 42, 2010, p. 125-156. RODRIGUES, Kassia. Das páginas ao corpo: escravidão e práticas de saúde em manuais de fazendeiros do século XIX. Dissertação (Mestrado em História) — Faculdade de Formação de Professores, Universidade do Estado do Rio de Janeiro, São Gonçalo (RJ), 2011.

${ }^{27}$ Apud MARQUESE, Rafael. Feitores do corpo, missionais da mente: senhores, letrados e o controle dos escravos nas Américas, 1660-1860, op. cit., p. 291.

${ }^{28}$ Marquese, citando Alencastro, afirmou que: "na década de 1820 alguns intelectuais e homens de Estado vinham defendendo o que Luís Felipe de Alencastro denominou de 'territorializaçáo' do mercado de trabalho no Brasil, ou seja, a necessidade de reproduçáo da mão de obra das plantations brasileiras ocorrer nos marcos territoriais do Estado Nacional, e não fora deles, medida vista como capaz de responder à pressão inglesa e garantir a continuidade a longo prazo da escravidáo". MARQUESE, Rafael. Feitores do corpo, missionais da mente: senhores, letrados e o controle dos escravos nas Américas, 1660-1860, op. cit., p. 297. 
E DEPOIS DA “LEI EUSÉBIO”? REPRODUÇÃO DA ESCRAVIDÃo E SEUS LIMITES EM UM COMPLEXO DE FAZENDAS DO VALE DO CAFÉ (RIO DE JANEIRO, C. I 864-I 888)

Thiago Campos Pessoa

baseada nas condiçôes ideais para formação da família escrava, e, consequentemente, na possibilidade de reiteração ampliada de sua demografia. ${ }^{29}$

Em diferentes realidades, a perspectiva de reprodução ampliada da escravidáo, nos marcos das grandes e médias propriedades, apareceu de maneira mais evidente na historiografia. Certamente o caso mais conhecido advém dos debates suscitados em torno do caráter da sociedade e da economia mineira, no lastro da crise da segunda metade do século XVIII. As teses dos irmãos Martins, ${ }^{30}$ analisadas por Slenes, Cano \& Luna, e Libby, tão caras ao desenvolvimento dos estudos da escravidão na Província de Minas Gerais, suscitaram o debate provocando o adensamento de um profícuo campo de análise que, entre tantos avanços, evidenciou a importância da reprodução endógena da escravidáo na complexa e diversa realidade escravista mineira. ${ }^{31}$ Libby \& Paiva destacaram, há quase duas décadas, que no limiar da ilegalidade do tráfico a populaçâo escrava de Minas Gerais já se reproduzia à margem do mercado, embora ainda muito marcada pelos fluxos do tráfico atlântico, incidente de maneira ilegal até os primeiros anos da década de 1850. França Paiva atestara também a ampla presença de nascimentos nas maiores escravarias, conjugados com a reabertura do tráfico nos anos de 1830. A demografia da escravidáo, naquela realidade, conjugava a vinda dos últimos africanos ao crescimento natural, em uma escravaria cada vez mais crioula. ${ }^{32}$ Esse perfil de crescimento vegetativo na escravidáo mineira quase sempre apareceu vinculado às propriedades dedicadas à produção de abastecimento e ao mercado interno, embora também estivesse presente na produção cafeeira da Zona da Mata. ${ }^{33}$

Em outras províncias, em contextos quase sempre desvinculados da grande lavoura de exportação, a perspectiva de reprodução endógena também foi denotada através da presença significativa de crianças em comunidades essencialmente crioulas, e que tendiam ao equi-

${ }^{29}$ SALLES, Ricardo. E o vale era o escravo, Vassouras, século XIX. Senhores e escravos no coração do império, op. cit., p. 250-254.

${ }^{30}$ Fazemos referência, principalmente, aos seguintes trabalhos: MARTINS, Roberto Borges. Minas Gerais, século XIX. Tráfico e apego à escravidão em uma economia não exportadora. Estudos Econômicos, v. 13, n. 11, p. 181-209, jan./abr. 1983. MARTINS FILHO, Amílcar; MARTINS, Roberto Borges. Slavery in a non-export economy: nineteenth century Minas Gerais revisited. Hispanic American Historical Review, v. 63, n. 3, p. 537-568, 1983.

${ }^{31}$ Não retomaremos os conhecidos debates realizados pelos autores citados, para tanto, Cf.: SLENES, Robert. Os múltiplos de porcos e diamantes: a economia escrava de Minas Gerais no século XIX. Estudos Econômicos, v. 18, n. 3, 1988. CANO, Wilson; LUNA, Francisco Vidal. A reprodução natural de escravos em Minas Gerais (século XIX): uma hipótese. In: LUNA, Francisco Vidal; COSTA, Iraci del Nero da; KLEIN, Herbert (Orgs.). Escravismo em São Paulo e Minas Gerais. São Paulo: Edusp, 2009, p. 499-509.

32 PAIVA, Clotilde Andrade; LIBBY, Douglas Cole. Caminhos alternativos: escravidão e reprodução em Minas Gerais no século XIX. Estudos Econômicos, v. 25, n. 2, p. 203-233, maio/ago. 1995. PAIVA, Eduardo França. Escravidão e universo cultural na colônia: Minas Gerais: 1716-1789. Belo Horizonte: UFMG, 2001, p. $147-148$.

${ }^{33}$ Para a regiáo de Juiz de Fora, vinculada à cafeicultura da Zona da Mata mineira, cf. FREIRE, Jonis. Crescimento da população cativa em uma economia agroexportadora: Juiz de Fora (Minas Gerais), século XIX. Revista de História, São Paulo, n. 166, p. 245-283, jan./jun. 2012. 
E DEPOIS DA “LEI EUSÉBIO”? REPRODUÇÃO DA ESCRAVIDÃo E SEUS LIMITES EM UM COMPLEXO DE FAZENDAS DO VALE DO CAFÉ (RIO DE JANEIRO, C. I 864-I 888)

Thiago Campos Pessoa

líbrio sexual. Assim, destacaram os estudos de Gutiérrez para a realidade paranaense em 1830; de Garavazo \& Marcondes para a região de Batatais, no nordeste de São Paulo, em 1875; e de Adriana Campos para a província do Espírito Santo entre os recortes de 17901819 e 1850-1871. ${ }^{34}$ Apesar das singularidades que distinguem cada uma dessas realidades, há elementos que as aproximam e produzem um quadro favorável à reprodução endógena da escravidão. Em tom especulativo, Costa, Slenes e Schwartz evidenciaram de maneira pioneira o mesmo para as médias e grandes escravarias de Lorena em 1801:

(...) De toda sorte, parece-nos que o contributo situado acima de um quarto [de filhos legítimos nas escravarias de 20 a 41 cativos] revela-se táo significativo que nos faz pensar no grande impulso potencial que os casamentos regulares podiam significar para a reposição ou ampliação dos plantéis com mais de dez escravos; esta evidência pode explicar por que, dos proprietários aqui analisados, os maiores parecem ter-se servido apenas subsidiariamente do mercado interno de escravos; ademais, talvez aí repousasse uma das causas para as hipotéticas proibiçóes aos escravos de se casarem fora de seus plantéis, pois os casamentos dentro (...) atuariam no sentido de garantir a "captação" integral dos rebentos que porventura viessem a ser concebidos. ${ }^{35}$

Sendo assim, a perspectiva do comendador em criar as condiçóes necessárias para o crescimento da fecundidade em suas comunidades, e ao mesmo tempo projetar a renda material e imaterial advinda desse processo, não era absolutamente novidade, como atestam a realidade oitocentista mineira e outras áreas do Sudeste, especialmente aquelas vinculadas à produção destinada ao mercado interno. No entanto, em relação à grande lavoura, boa parte dos pesquisadores que se dedicaram a estudá-la enfatizou justamente o contrário: a incapacidade de reprodução interna de sua demografia, devido, especialmente, aos elevados índices de masculinidade e às altas taxas de mortalidade. Assim, a tendência apontada por Costa, Slenes e Schwartz não se desdobrou em densas pesquisas sobre as realidades demográficas do Vale cafeeiro fluminense. ${ }^{36}$ Talvez, por isso, com exceção do trabalho de Salles, a pers-

\footnotetext{
${ }^{34}$ GUTIÉRREZ, Horácio. Demografia escrava numa economia não-exportadora: Paraná, 1800-1830. Estudos Econômicos, v. 17, n. 2, maio/ago. 1987. MARCONDES, Renato; GARAVAZO, Juliana. A propriedade escrava e a hipótese de crescimento vegetativo em Batatais: a classificação de escravos (1875). Texto apresentado no XIII Encontro da Associação Brasileira de Estudos Populacionais, realizado em Ouro Preto, Minas Gerais, de 4 a 8 de novembro de 2002. CAMPOS, Adriana. Escravidão, reprodução endógena e crioulização: o caso do Espírito Santo no oitocentos. Topoi, v. 12, n. 23, jul./dez., 2011, p. 84-96.

${ }^{35}$ COSTA, Iraci del Nero da; SLENES, Robert; SCHWARTZ, Stuart. A família escrava em Lorena (1801). In: LUNA, Francisco Vidal; COSTA, Iraci del Nero da; KLEIN, Herbert (Orgs.). Escravismo em São Paulo e Minas Gerais, op. cit., p. 543.

${ }^{36} \mathrm{O}$ mesmo não se pode dizer em relação à porção paulista do Vale. Para tanto, cf. MOTTA, José Flávio. Corpos escravos, vontades livres: posse de cativos e família escrava em Bananal (1801-1829). São Paulo: Annablume, 1999. MARCONDES, Renato Leite. A arte de acumular na economia cafeeira: Vale do Paraíba, século XIX. Lorena: Stiliano, 1998. MORENO, Breno. Demografia e trabalho escarvo nas propriedades escravas de
} 
E DEPOIS DA “LEI EUSÉBIO”? REPRODUÇÃO DA ESCRAVIDÃo E SEUS LIMITES EM UM COMPLEXO DE FAZENDAS DO VALE DO CAFÉ (RIO DE JANEIRO, C. I 864-I 888)

Thiago Campos Pessoa

pectiva de que as plantations brasileiras não eram capazes de reproduzir sua demografia, ao contrário de suas congêneres no Sul dos EUA, ainda parece lugar-comum nos estudos sobre os complexos cafeeiros no eixo Vale-Oeste Paulista.

Os estudos de Stein e Dean talvez sejam os mais assertivos nesse sentido. Logo nas primeiras páginas de seu belo livro sobre Vassouras, Stein desmarcara que "no Brasil, ao contrário dos Estados Unidos, os escravos simplesmente não se reproduziam. Também os senhores náo modificariam de maneira apreciável a carga de trabalho, disciplina e condiçóes gerais de vida dos trabalhadores escravos". ${ }^{37}$ Dean, preso ao paradigma de seu tempo, reproduz a assertiva de Stein, muito embora seus dados apontassem na direçáo contrária. Rio Claro, em 1872, contava com a presença significativa de mulatos em mais de $1 / 4$ da escravaria, grupo "quase inexistente entre 1822 e 1835"; além de uma ampla expansão dos crioulos entre 1835 e 1871 , que saltaram de $42,9 \%$ para $82,5 \%$ da população escrava em 1872 . No mesmo ano, para cada 100 cativas entre 16 e 60 anos, havia 55,5 crianças, sendo esse número mais que o dobro $(128,5)$ entre as mulheres tidas por mulatas. Contraditoriamente, argumentara que o crescimento dessa população, na segunda metade do século, se relacionava apenas à "chegada de escravos de outros municípios" uma vez que "a populaçáo escrava não se reproduzia"38.

Viotti da Costa, na segunda edição de Da senzala à colônia, enfatizara o parco desenvolvimento demográfico da populaçáo escrava, "em razão da balança negativa entre natalidade e mortalidade dos escravos". ${ }^{39}$ De igual modo, mais recentemente, João Fragoso reafirmara tal perspectiva. Segundo o autor: "Os meus dados sobre Paraíba do Sul contrariam a hipótese de tal crescimento natural da população escrava, capaz de sustentar as grandes fazendas de café com trabalhadores entre 14 e 40 anos depois da abolição do tráfico atlântico negreiro em $1850 " .40$

A assertiva de Fragoso segue embasada em vasta análise documental sobre realidade demográfica de Paraíba do Sul entre 1830 e 1888, enquanto a conclusão de Viotti da Costa acompanha importantes pesquisas realizadas por Dean, Eisenberg, Carvalho de Melo e Slenes, nas quais as taxas de mortalidade superavam os índices de natalidade entre a população escrava. A autora cita, por exemplo, dados em que Slenes enfatiza que entre os filhos de cativas da Corte, nascidos nos anos de 1871 e 1887, o índice de mortalidade, embora fosse menor do que se supunha — 232 por 1.000 , entre os indivíduos de 0 a 16 anos —, não parecia suficiente para garantir um crescimento vegetativo da escravaria. Concluindo, demarca

Bananal, 1830-60. Dissertação (Mestrado em História) - Faculdade de Filosofia, Letras e Ciências Humanas, Universidade de São Paulo, São Paulo, 2013.

${ }^{37}$ STEIN, Stanley. Vassouras: um município brasileiro do café (1850-1900), op. cit., p. 20.

${ }^{38}$ DEAN, Warren. Rio Claro: um sistema brasileiro de grande lavoura (1850-1920). Rio de Janeiro: Paz e Terra, 1977, p. 72. Os demais dados aparecem compilados entre as páginas 61-73.

${ }^{39}$ COSTA, Emília Viotti. Da senzala à colônia. São Paulo: Ciências Humanas, 1982. p. 36 (Prefácio à Segunda Edição, 1982).

${ }^{40}$ FRAGOSO, João. Baróes do café e sistema agrário escravista: Paraíba do Sul/Rio de Janeiro (1830-1888). Rio de Janeiro: 7Letras, 2013, p. 19. 
que "contraditoriamente ao que se dá nos Estados Unidos, onde os índices de natalidade são bastante altos, a população escrava no Brasil tende a diminuir a partir da cessão do tráfico" ${ }^{41}$

Pesquisas posteriores à escrita de Viotti da Costa mostraram justamente o contrário. A continuidade dos estudos do próprio Slenes evidenciaram que na regiáo do Vale fluminense, especialmente em sua banda oriental, a demografia escrava seguiu em ritmo de crescimento até pelo menos o final da década de $1870 .{ }^{42}$ Embora devamos relativizar essa ampliação para determinadas áreas do Vale ocidental fluminense, de maneira geral, o crescimento destacado por Slenes segue incontestável em relação à macrorregião cafeeira. Sua análise, estabelecida através de dados censitários e dos fluxos de entrada e saída de cativos em diferentes municípios da grande lavoura fluminense, demonstra um mercado de escravos ativo e expansão naqueles anos em direção às zonas economicamente mais ativas do Império. Os dados do autor não comportam informaçóes sobre o nascimento de ingênuos para o mesmo período, o que talvez pudesse indicar que a dinâmica do mercado de escravos fosse acompanhada pela ampliação da demografia daqueles complexos através da reprodução interna de suas comunidades escravas.

Obviamente, por ora, essa perspectiva não deve ser generalizada para a realidade das amplas fazendas do Vale, uma vez que não dispomos de dados que a comprove. Entretanto, em razão do que analisamos, parece bastante acertado supor que a reprodução endógena daquelas comunidades era uma realidade que se desenhava desde o final da década de 1860, sendo corporificada nos anos seguintes, já sob a vigência do Ventre Livre. Podemos propor que em áreas onde a crise se instaurou mais cedo, já na década de 1870, e o crescimento da demografia escrava via mercado foi reduzido, como notamos para Piraí, ou ainda negativo, como no caso de São João do Príncipe, o recurso ao desenvolvimento endógeno da demografia daquelas fazendas se fez urgente. Nesse sentido, o quadro consagrado na historiografia tradicional de que as grandes lavouras escravistas brasileiras náo apresentavam as condiçóes necessárias para reprodução interna de sua população parece distante da realidade encontrada em um amplo conjunto de fazendas do médio Vale fluminense.

De maneira geral, o que fica dessa aproximação demográfica a um dos maiores complexos escravistas do Império é que seu desenvolvimento parece indicar uma ampla capacidade reprodutiva da escravidão em suas fronteiras, ao menos entre meados das décadas de 1860 e 1870. Na segunda metade do século XIX, a reestruturação do complexo Breves conjugou o fechamento do tráfico à perspectiva de crescimento e reprodução da escravidão nos marcos do Estado Nação, como parecem indicar os manuais agrícolas e as realidades das grandes comunidades escravas daquele tempo. Também, por isso, o projeto que dera origem à famosa lei do "Ventre Livre" fora alvo de diversas petições das câmaras dos municípios cafeeiros,

\footnotetext{
${ }^{41}$ COSTA, Emília Viotti. Da senzala à colônia, op. cit., p. 36, nota 6.

${ }^{42}$ SLENES, Robert. Grandeza ou decadência? O mercado de escravos e a economia cafeeira da provincia do Rio de Janeiro 1850-1888. In: COSTA, Iraci del Nero da (Org.). Brasil: história econômica e demográfica. São Paulo: IPE/USP, 1986, p. 103-149.
} 
E DEPOIS DA “LEI EUSÉBIO”? REPRODUÇÃO DA ESCRAVIDÃo E SEUS LIMITES EM UM COMPLEXO DE FAZENDAS DO VALE DO CAFÉ (RIO DE JANEIRO, C. I 864-I 888)

Thiago Campos Pessoa

que arguiam em favor da revogação da matéria, da mesma forma que fizeram nas diversas tentativas de anular a lei que abolira o tráfico em 1831.

Entretanto, o fim da possibilidade de reproduzir a escravidão nos marcos das porteiras das grandes fazendas não implicou a retração ao estímulo às famílias e aos nascimentos naqueles espaços. Ao contrário, guardado o devido nível de liberdade e expectativa presente entre os próprios cativos, possivelmente os senhores apropriaram-se da possibilidade de angariarem alguma renda política e econômica com o trabalho futuro dos ingênuos, o que se comprova pelo fato de que quase nenhum deles optou por entregar as crianças à tutela do Estado mediante indenizaçáo pelos serviços prestados. ${ }^{43}$ Nesse processo, se fortalecia a família vinda da escravidão, que na contradição da vida ampliava a autonomia da sua comunidade, ao mesmo tempo que recriava, em bases mais frágeis, a dominação dos antigos senhores e suas expectativas de governo ainda marcadas por um caráter eminentemente escravista. Assim, grandes senhores como Breves buscavam nos próprios laços familiares tecidos por sua ampla comunidade escrava reconstruir e ressignificar os mecanismos de dominação e submissão, que à época viabilizavam o já ofegante complexo escravista do vale cafeeiro fluminense.

\section{Referências bibliográficas}

CAMPOS, Adriana. Escravidão, reprodução endógena e crioulização: o caso do Espírito Santo no oitocentos. Topoi, v. 12, n. 23, p. 84-96, jul./dez., 2011.

CANO, Wilson; LUNA, Francisco Vidal. A reprodução natural de escravos em Minas Gerais (século XIX): uma hipótese. In: LUNA, Francisco Vidal; COSTA, Iraci del Nero da; KLEIN, Herbert. Escravismo em São Paulo e Minas Gerais. São Paulo: Edusp, 2009, p. 499-509.

CARVALHO, José Murilo de. Teatro das sombras. A política imperial. São Paulo: Vértice, 1988. . A construção da ordem/Teatro de Sobras. 3. ed. Rio de Janeiro: Civilizaçáo Brasileira, 2007.

CHALHOUB, Sidney. Machado de Assis, historiador. São Paulo: Companhia das Letras, 2003.

Coletânea LABHOI-UFF. Passados Presentes, 2012. (4 DVDs)

COSTA, Emília Viotti. Da senzala à colônia. São Paulo: Ciências Humanas, 1982.

COSTA, Iraci del Nero da; GUTIÉRREZ, Horácio. Nota sobre casamento de escravos em São Paulo e Paraná (1830). In: COSTA, Iraci del Nero da; KLEIN, Herbert; LUNA, Francisco Vidal. Escravismo em São Paulo e Minas Gerais. São Paulo: Edusp, 2009, p. 511-518.

DEAN, Warren. Rio Claro: um sistema brasileiro de grande lavoura (1850-1920). Rio de Janeiro: Paz e Terra, 1977.

${ }^{43}$ Cf. CHALHOUB, Sidney. Machado de Assis, historiador. São Paulo: Companhia das Letras, 2003. 
E DEPOIS DA “LeI EUSÉBIO”? REPRODUÇÃO DA ESCRAVIDÃo E SEUS LIMITES EM UM COMPLEXO DE FAZENDAS DO VALE DO CAFÉ (RIO DE JANEIRO, C. I 864-I888)

EUGÊNIO, Alisson. Reflexóes médicas sobre as condiçôes de saúde da população escrava no Brasil do século XIX. Afro-Ásia, n. 42, p. 125-156, 2010.

FLORENTINO, Manolo; GOES, José Roberto. A paz das senzalas: famílias escravas e tráfico atlântico, c. 1790-c. 1850. Rio de Janeiro: Civilização Brasileira, 1997.

FRAGOSO, João. Barōes do café e sistema agrário escravista: Paraíba do Sul/Rio de Janeiro (1830-1888). Rio de Janeiro: 7Letras, 2013.

FREIRE, Jonis. Crescimento da populaçâo cativa em uma economia agroexportadora: Juiz de Fora (Minas Gerais), século XIX. Revista de História, Sáo Paulo, n. 166, p. 245-283, jan./ jun. 2012.

GRAHAM, Richard. Patronage and Politics in Nineteenth-century Brazil. Califórnia: Stanford University Press, 1989.

GUTIÉRREZ, Horácio. Demografia escrava numa economia não-exportadora: Paraná, 1800-1830. Estudos Econômicos, v. 17, n. 2, maio/ago. 1987.

LAMEGO, Alberto. O homem e a restinga. Rio de Janeiro: IBGE - Conselho Nacional de Geografia, 1946.

LARA, Silvia (Org.). Ordenaçôes Filipinas. Livro V. São Paulo: Companhia das Letras, 1999. MARCONDES, Renato Leite. A arte de acumular na economia cafeeira: Vale do Paraíba, século XIX. Lorena: Stiliano, 1998.

; GARAVAZO, Juliana. A propriedade escrava e a hipótese de crescimento vegetativo em Batatais: a classificaçáo de escravos (1875). Texto apresentado no XIII Encontro da Associação Brasileira de Estudos Populacionais, realizado em Ouro Preto, Minas Gerais, de 4 a 8 de novembro de 2002.

MARQUESE, Rafael. Feitores do corpo, missionários da mente: senhores, letrados e o controle dos escravos nas Américas, 1660-1860. São Paulo: Companhia das Letras, 2004.

MARTINS, Roberto Borges. Minas Gerais, século XIX. Tráfico e apego à escravidão em uma economia não exportadora. Estudos Econômicos, v. 13, n. 11, p. 181-209, jan./abr. 1983.

MARTINS FILHO, Amílcar; MARTINS, Roberto Borges. Slavery in a non-export economy: nineteenth century Minas Gerais revisited. Hispanic American Historical Review, v. 63 , n. 3, 1983, p. 537-568.

MATTOS, Hebe; SCHNOOR, Eduardo. Resgate: uma janela para o oitocentos. Rio de Janeiro: Topbooks, 1995.

- Racialização e cidadania no Império do Brasil. In: CARVALHO, José Murilo de; NEVES, Lúcia Maria Bastos Pereira das. Repensando o Brasil do Oitocentos. Rio de Janeiro: Civilização Brasileira, 2009, p. 341-391.

. Das cores do silêncio: os significados da liberdade no sudeste escravista - Brasil, século XIX. ed. rev. Campinas: Unicamp, 2013. 
E DEPOIS DA “LeI EUSÉBIO”? REPRODUÇÃO DA ESCRAVIDÃo E SEUS LIMITES EM UM COMPLEXO DE FAZENDAS DO VALE DO CAFÉ (RIO DE JANEIRO, C. I 864-I 888)

Thiago Campos Pessoa

MORENO, Breno. Demografia e trabalho escarvo nas propriedades escravas de Bananal, 1830-60. Dissertação (Mestrado em História) — Faculdade de Filosofia, Letras e Ciências Humanas, Universidade de São Paulo, São Paulo, 2013.

MOTTA, José Flávio. Corpos escravos, vontades livres: posse de cativos e família escrava em Bananal (1801-1829). São Paulo: Annablume, 1999.

. Escravos daqui, dali e de mais além: o tráfico interno de cativos na expansão cafeeira paulista. São Paulo: Alameda Editorial, 2012.

PAIVA, Clotilde Almeida; LIBBY, Douglas Cole. Caminhos alternativos: escravidáo e reprodução em Minas Gerais no século XIX. Estudos Econômicos, v. 25, n. 2, p. 203-233, maio/ago. 1995.

PAIVA, Eduardo França. Escravidão e universo cultural na colônia: Minas Gerais: 1716-1789. Belo Horizonte: UFMG, 2001.

PENA, Eduardo Spiller. Pajens da Casa Imperial. Jurisconsulto, Escravidão e a Lei de 1871. Campinas: Ed. da Unicamp/Cecult, 2001.

PESSOA, Thiago Campos. A Indiscrição como oficio: o complexo cafeeiro revisitado (Rio de Janeiro, c. 1830 - 1888). Tese (Doutorado em História) - Instituto de Ciências Humanas e Filosofia, Universidade Federal Fluminense, Niterói, 2015.

. O Império da Escravidão: o complexo Breves no vale do café (Rio de Janeiro, c. 1850-1888). Rio de Janeiro: Arquivo Nacional, no prelo.

PORTO, Ângela. O sistema de saúde do escravo no Brasil do século XIX: doenças, instituiçóes e práticas terapêuticas. História, Ciências, Saúde - Manguinhos. Rio de Janeiro, v. 13, n. 4, p. 119-127, out./dez. 2006.

RODRIGUES, Kassia. Das páginas ao corpo: escravidão e práticas de saúde em manuais de fazendeiros do século XIX. Dissertação (Mestrado em História) — Faculdade de Formação de Professores, Universidade do Estado do Rio de Janeiro, Sáo Gonçalo (RJ), 2011.

SALLES, Ricardo. E o vale era o escravo: Vassouras, século XIX. Senhores e escravos no coração do império. Rio de Janeiro: Civilização Brasileira, 2008.

SILVA, Eduardo. Barôes e escravidão - três geraçôes de fazendeiros e a crise da estrutura escravista. Rio de Janeiro: Nova Fronteira, 1984.

SLENES, Robert. The demography and economics of brazilian slavery, 1850-1888. Tese (Doutorado em História) — Stanford University, Stanford, 1976.

- Grandeza ou decadência? O mercado de escravos e a economia cafeeira da província do Rio de Janeiro 1850-1888. In: COSTA, Iraci del Nero da (Org.). Brasil: história econômica e demográfica. São Paulo: IPE/USP, 1986, p. 103-149.

. Os múltiplos de porcos e diamantes: a economia escrava de Minas Gerais no século XIX. Estudos Econômicos, v. 18, n. 3, 1988.

. "Malungo ngoma vem!": África coberta e descoberta no Brasil!. Revista USP, São 
E DEPOIS DA “LEI EUSÉBIo”? REPRODUÇÃO DA ESCRAVIDÃo E SEUS LIMITES EM UM COMPLEXO DE FAZENDAS DO VALE DO CAFÉ (RIO DE JANEIRO, C. I 864-I 888)

Paulo, n. 12, p. 48-67, 1992.

. Na senzala uma flor: esperanças e recordaçóes da família escrava - Brasil, Sudeste

— século XIX. Rio de Janeiro: Nova Fronteira, 1999.

STEIN, Stanley. Vassouras: um município brasileiro do café (1850-1900). Rio de Janeiro: Nova Fronteira, 1990.

SCHWARTZ, Stuart. Segredos internos: engenhos e escravos na sociedade colonial (15501835). São Paulo: Companhia da Letras, 1995.

TAUNAY, Carlos Augusto. Manual do agricultor brasileiro. Organização Rafael Marquese. São Paulo: Companhia das Letras, 2001.

\section{Fontes primárias}

Arquivo Municipal de Piraí (AMP)

- Livro de controle interno das fazendas do Comendador Joaquim Breves (1864-1888). Arquivo Nacional (AN)

- Apelação crime, 1874. Fundo: Tribunal da Relação (84) no 3.368, maço 97, galeria A.

Museu da Justiça do Estado do Rio de Janeiro (MJERJ)

- Inventário de Joaquim José de Souza Breves (1889).

Center for Research Libraries (CRL)

- Mapa especial do movimento da população ingênua até 31 de dezembro de 1877 nos diversos municípios da Província do Rio de Janeiro. Brazilian Government Document Digitalization Project. Provincial Presidential Reports (1830-1930): Rio de Janeiro, 1878.

- Quadro estatístico dos filhos livres de mulher escrava, matriculados até 31 de dezembro de 1878 com as alteraçóes ocorridas até aquela data. Rio de Janeiro, 1879. Brazilian Government Document Digitalization Project. Provincial Presidential Reports (1830-1930).

- Brazilian Government Documents. Provincial Presidential Reports (1830-1930). Província do Rio de Janeiro. 1883.

Instituto Brasileiro de Geografia e Estatística (IBGE)

- Diretoria Geral de Estatística, Recenseamento Geral do Império de 1872. Rio de Janeiro: Typ. Leuzinger/Tip. Commercial, 1876, 12 v.

\section{Como citar}

PESSOA, Thiago Campos. E depois da "Lei Eusébio"? Reproduçáo da escravidão e seus limites em um complexo de fazendas do vale do café (Rio de Janeiro, c. 1864-1888). Topoi. Revista de História, Rio de Janeiro, v. 18, n. 36, p. 465-489, set./dez. 2017. Disponível em: $<$ www.revistatopoi.org $>$. 